\title{
Biomarkering metabolic activities of the tapeworm Khawia armeniaca (Cholodkovsky, 1915) in association to its fish host Barbus grypus (Hekle, 1843)
}

\author{
B.H. Al-Niaeemi ${ }^{1}$ and M.H. Dawood ${ }^{2}$ \\ 1Department of Basic Nursing Science, College of Nursing, 2Department of Clinical Laboratory Science, College of \\ Pharmacy, University of Mosul, Mosul, Iraq
}

\begin{tabular}{l} 
Article information \\
\hline Article history: \\
Received January 07, 2020 \\
Accepted April 25, 2020 \\
Available online November 1, 2020 \\
\hline Keywords: \\
Khawia armeniaca \\
Barbus grypus \\
LDH \\
AST \\
ALT \\
Macromoleculed \\
\hline Correspondence: \\
M.H. Dawood \\
maruahammoshi@gmail.com
\end{tabular}

DOI: $10.33899 /$ ijvs.2020.126518.1339, (02021, College of Veterinary Medicine, University of Mosul. This is an open access article under the CC BY 4.0 license (http://creativecommons.org/licenses/by/4.0/).

\section{Introduction}

Stress factors like some infections, toxicants, hypoxia and heavy metals pollution could be affecting enzymatic activity in animals. Thus, assessing the alteration in activity of particular enzymes is really helpful to pursue body disorders. When an organ is diseased due to the effect of intrinsic factors, enzyme activity appears to be increased or it may be inhibited due to the active site being either denatured or distorted (1-4). Proteins, lipids and carbohydrates are abundant and important biomolecules in living organisms including parasites. They have important role in life maintenance in the cell (4). Some researchers were concern with studying metabolism of protein, carbohydrates, lipid and related enzymes in fish cestodes like Aisien and Ogiji those studied lipid metabolism in the 
tapeworm Oochoristica agamae (5), Malagón et al. those studied carbohydrate metabolism in the fish tapeworm Hysterothylacium aduncum (6), Al-Naftachi that studied protein, carbohydrate and lipids metabolism in snake, bird and fresh water fish tapeworms (7), Waghmare and Chavan those studied carbohydrate metabolites in cestode parasites of Gallus gallus domesticus (8), Dawood et al. those studied energy metabolism in the house frog cestode Ophiotaenia bofonis and the domestic pigeon tapeworm Cotugnea columbae (9), Al-Niaeemi and Dawood those studied lipids and fatty acids metabolism of Bothriocephalus acheilognathi, tapeworm of the common carp (10) and Al-Niaeemi et al. those studied proteins and carbohydrates metabolism in the tapeworm Postgangesia armata that infect Siluris glanis fish (11).

Enzymes like LDH, AST and ALT are present in most tissues and catalyze some steps in the metabolism of carbohydrates and protein; thus, the increase or decrease in their level may be sufficient to provide information of diagnostic value. Actually, alteration in such enzymes activity is necessary for maintaining equilibrium convoy stress effects like endoparasites, which may disrupt physiological and biochemical processes (12).

The level of LDH activity and the functional properties of this enzyme marking the capacity for anaerobic energy production and, thereby, the level of resistance to oxygen deficiency during hypoxia, vigorous exercise or thermal stress, LDH also serves to remove lactate during aerobic recovery, especially in tissues such as liver and heart (13). Furthermore, LDH is one of the guide that could be used to quantify early heart damage (14).

AST is found in the liver, heart, skeletal muscle, kidneys, brain, and red blood cells (15). AST catalyzes the reversible transfer of $\alpha$-amino group between aspartate and glutamate and, as such, is an important enzyme in amino acid metabolism.

AST plays a key role in carbohydrate and protein metabolism especially in the liver, where the higher density of the enzyme exists. This enzyme is released into the blood as the result of liver damages, so its measurement is an index in the evaluation of hepatocellular injury (12). However, they may also be elevated in other conditions such as thyroid disorders, celiac disease, and muscle disorders (16).

Alanine aminotransferase (ALT) or called glutamatepyruvate transaminase (GPT) is one of the aminotransferases (transaminases) enzymes, which catalyzes the transfer of the amino group (NH2) from alanine to $\alpha$-ketoglutarate. It plays a key role in carbohydrate and protein metabolism especially in the liver, where the higher density of the enzyme exists (12).

ALT is released into the blood as the result of liver damages, so its measurement is an index in the evaluation of hepatocellular injury (17). Fluctuation of ALT levels is normal over the course of the day, and they can also increase in response to strenuous physical exercise (16). Changes in activity of LDH, AST and ALT, added to alterations in the metabolism of protein and carbohydrate were frequently used for evaluating destructive effect of some stress factors on fish tissues (18-20). Nambati et al. (21) was reported a decrease in total protein and albumin and increase in the hepatic enzymes ALT, AST, and alkaline phosphatase in fish infected with some species of protozoa.

As for endoparasites, ALT and AST have been measured in various species of parasites including two species of nematodes Ascaris lumbricoides and Ascaridia galli, five species of trematodes Clonorchis sinensis, F. gigentica, Eurytrema pancreaticum, Paramphistomum cervi and Paragonimus westermani and five species of cestodes Diphyllobothrium mansoni, Dipylidium caninum, Taenia pisiformis, Cysticercus cellulosae and Cysticercus pisiformis (20-23).

Thus, the present study was aimed to estimate the activity of LDH and some transaminase enzymes in tissues of the intestinal tapeworm Khawia armeniaca and its host, Barbus grypus fish, then combined between enzymes activity and biomolecules level in both the host fish and the parasitic tapeworm, trying to explain relationship between the parasite and its host from the biochemical ambience.

\section{Material and methods}

\section{Specimen collection}

57 adult Barbus grypus fish were hunted from Tigris river in Rashidiya area in the north of Mosul in Iraq. The collection was made between November 2018 and May 2019. The hunted fish then dissected in the research lab, Biology Department, College of Science, University of Mosul. The adult tapeworm $K$. armeniaca were collected from the upper part of small intestine of the fish.

The collected helminthes were washed several times with PBS ( $\mathrm{pH}$ 7.4), put in Petridis, examined under Hamilton dissecting microscope. Wet weight for each helminth was fixed. Then frozen at $-18^{\circ} \mathrm{C}$. Some helminthes were prepared for classification (fixed, dehydrated, clarified and mounted by DPX). Classification was performed in Department of Biology, College of Science, University of Mosul, depending on (24). Furthermore, small intestine and liver of the infected and some uninfected Barbus grypus fish were cut, cleaned, washed with $\mathrm{PBS} \mathrm{pH} 7.8$, fresh Weight was fixed for each sample then then frozen at $-18^{\circ} \mathrm{C}$ for the subsequent biochemical assessments.

\section{Preparation of worms and fish liver and intestine extracts}

The worms and parts of infected and uninfected fish intestines and liver were suspended in a $0.05 \mathrm{M}$ Tris- $\mathrm{HCl}$ buffer 7.8 at a concentration of $10 \%$ wet weight/volume; then the suspension was homogenized in a tissue grinder. 
Cell membranes disrupted using ultrasonic disintegration (MSE), a 12000 vibration/second for 30 second in ice-bath. Four cycles of sonication were applied with the suspension. Ultracentrifugation at $15000 \mathrm{~g} / 30$ minutes was done using MSE super speed cooled ultracentrifuge. The supernatant fraction was chosen for excessive biochemical studies (7).

\section{Estimation of total carbohydrates}

Gottschalk method (25) was used to estimate carbohydrates concentration in the worms and fish intestine extracts. Absorbance was measured at $488 \mathrm{~nm}$. Carbohydrate concentration were estimated depending on carbohydrate standard curve.

\section{Estimation of total proteins}

Schscterle and Pollack colorimetric method (26) was adopted to estimate concentration of protein in the worms and fish intestine and liver extracts. Absorbance was measured at $750 \mathrm{~nm}$. Protein slandered curve was used to estimated concentration of protein.

\section{Estimation of total lipids}

Chabrol and Chardonnet colorimetric method was used to evaluate whole lipids content (26). $20 \mu \mathrm{L}$ of worms and fish intestine extracts was heated with concentrated sulphoric acid. Phosphovaniline indicator was added to the mixture to produce purple-red color complex. Absorbance were determined at $540 \mathrm{~nm}$. Whole lipids in each sample were estimated depending on the rule:

Whole lipids concentration $\mathrm{mg} / 100 \mathrm{~cm}=$

$$
\frac{\text { sample absorbance }- \text { blank absorbance }}{\text { standered absorbance }- \text { blank absorbance }} \times 500
$$

Assay system for Lactate dehydrogenase (LDH) activity

LDH activity were evaluated in $K$. armeniaca tissues and liver extract of the infected and uninfected B. grypus fish, depending on a method adopted by Wolf (27). LDH reduce pyruvate to lactate in the presence of NADH (cofactor). A specific analysis set, provided by Biomerierux/France was used. Estimation of LDH activity depends on the reaction between the residual pyruvate and 2,4-Dinitrophenyl hydrazine, which produce a reddish brown complex of Pyruvate hydrazone at basic media. Absorption measured at $365 \mathrm{~nm}$.

\section{Assay system for Aspartate aminotransaminase (AST)}

activity of AST activity was estimated in $K$. armeniaca tissues and liver extract of the infected and uninfected $B$. grypus depending on Reitman and Frankel method (28). AST convert Aspartate to oxaloacetate. A specific analysis set, provided by Biomerierux/France was used. 2,4dinitrophenyl hydrazine (indicator) form reddish brown complex with oxaloacetate during the enzymatic reaction. Absorption of the complex can be measured by spectrophotometer at the wavelength $505 \mathrm{~nm}$. Concentration of AST was estimated depending on the slandered curve.

\section{Assay system for Alanine aminotransaminase (ALT)}

ALT induce conversion of alanine to pyruvate. Activity of ALT were estimated in $K$. armeniaca and liver extract of the infected and uninfected B. grypus fish, depending on Reitman and Frankel method (28). A specific analysis set, provided by Biomerierux/France was used. 2,4dinitrophenyl hydrazine (indicator) form reddish brown complex with oxaloacetate during the enzymatic reaction. Absorption of the complex can be measured by spectrophotometer at the wavelength $505 \mathrm{~nm}$. Concentration of ALT was estimated depending on the slandered curve.

\section{Statistical analysis}

ANOVA- Duncan's test was applied to find the difference in mean values between the tissues of the tapeworm, infected and non-infected fish at $\mathrm{P} \leq 0.05$ significant level (29). The data were processed using Statistical package for society software (SPSS) / version 14 for Windows to analyze the data by computer.

\section{Results}

In the present study, we have attempted to assess the exchange influence between the intestinal tapeworm $K$. armeniaca and its host $B$. grypus fish considering the metabolic activity in the host and it`s parasite, employing LDH and aminotransferase enzymes as biomarkers.

\section{Investigating macromolecules concentration}

Table 1 showed that proteins have the highest concentration than carbohydrates and lipids in both infected and uninfected fish, were as lipids has the highest concentration than proteins and carbohydrates in $K$. armeniac tissues. There was significant different at $\mathrm{P} \leq 0.05$ between average concentration of proteins, carbohydrates and lipids in the intestinal tissues of uninfected fish 264.70 $\mu \mathrm{g} / \mathrm{g}, 223.71 \mu \mathrm{g} / \mathrm{g}$ and $176.37 \mathrm{mg} / 100 \mathrm{~m}$, respectively when compared with that of the infected fish $176.92 \mu \mathrm{g} / \mathrm{g}, 147.21$ $\mu \mathrm{g} / \mathrm{g}$ and $112.14 \mathrm{mg} / 100 \mathrm{~m}$, respectively. Means that presence of the intestinal tapeworm leads to lowering biomolecules concentration in the infected Barbus grypus. The significant different was observed also between the average concentration of protein, carbohydrates and lipids in the tapeworm tissues $114.38 \mu \mathrm{g} / \mathrm{g}, 72.56 \mu \mathrm{g} / \mathrm{g}$ and 130.67 $\mathrm{mg} / 100 \mathrm{~m}$, respectively, when compared with that of the intestinal tissues of both the infected and uninfected Barbus grypus.

\section{Investigating lactate dehydrogenase and transaminase enzymes}

In the present work, table 2 illustrated that concentration of protein and activity of ALT in the liver of uninfected $B$. 
grypus fish was significantly higher than that of infected $B$. grypus. On the other hands, LDH activity was higher significantly at $\mathrm{P} \leq 0.05$ in the liver of infected fish than that of uninfected fish. No significant different were observed in the activity of AST in the liver of infected and uninfected fish. As for Concentration of protein and activity of the three enzymes LDH, AST and ALT in K. armeniaca tissues were lesser significantly at $\mathrm{P} \leq 0.05$ than that found in both the infected and the uninfected B. grypus fish.

Table 1: Total concentration of biomolecules in the intestinal tissues $K$. armeniaca tapeworm

\begin{tabular}{lccc}
\hline \multirow{2}{*}{ Biomolecules } & \multicolumn{3}{c}{ Macromolecules concentration (average \pm slandered deviation) } \\
\cline { 2 - 4 } & Intestine of uninfected fish & Intestine of infected fish & Tissues of K. armeniaca \\
\hline Proteins $(\mu \mathrm{g} / \mathrm{g}$ wet weight) & $264.70 \pm 6.129^{\mathrm{a}}$ & $176.92 \pm 5.481^{\mathrm{b}}$ & $114.38 \pm 3.789^{\mathrm{c}}$ \\
Carbohydrates $(\mu / \mathrm{g}$ wet weight $)$ & $223.71 \pm 6.386^{\mathrm{a}}$ & $147.21 \pm 7.340^{\mathrm{b}}$ & $72.56 \pm 4.185^{\mathrm{c}}$ \\
Lipids $(\mathrm{mg} / \mathrm{dl})$ & $176.37 \pm 6.380^{\mathrm{a}}$ & $112.14 \pm 3.347^{\mathrm{c}}$ & $130.67 \pm 4.223^{\mathrm{b}}$ \\
\hline
\end{tabular}

*Each value represent mean of three replicates \pm SD. **Different letters referred to presence of significant differences between the values at $\mathrm{P} \leq 0.05$, according to Duncan's- test.

Table 2: Total activity of enzyme in liver tissues of $K$. armeniaca tapeworm

\begin{tabular}{lcccc}
\hline \multirow{2}{*}{ Sample type } & \multicolumn{4}{c}{ Average \pm SD } \\
\cline { 2 - 5 } & Protein concentration & LDH activity IU/L & AST activity IU/L & ALT activity IU/L \\
\hline liver of uninfected fish & $192.85 \pm 2.821^{\mathrm{a}}$ & $253.56 \pm 18.548^{\mathrm{b}}$ & $130.52 \pm 3.357^{\mathrm{a}}$ & $90.13 \pm 2.836^{\mathrm{a}}$ \\
liver of infected fish & $132.09 \pm 4.391^{\mathrm{b}}$ & $279.9 \pm 11.930^{\mathrm{a}}$ & $128.90 \pm 1.750^{\mathrm{a}}$ & $63.65 \pm 4.331^{\mathrm{b}}$ \\
K. armeniaca tissue & $114.38 \pm 3.789^{\mathrm{c}}$ & $106.02 \pm 6.439^{\mathrm{c}}$ & $35.46 \pm 9.910^{\mathrm{b}}$ & $27.22 \pm 4.331^{\mathrm{c}}$ \\
\hline
\end{tabular}

*Each value represent mean of three replicates \pm SD. ${ }^{* *}$ Different letters referred to the significant differences between the values at $\mathrm{P} \leq 0.05$, according to Duncan's- test.

\section{Discussion}

In the present work, the results were coming agree with the findings of $(11,30,31)$ in terms of lower protein concentration in infected fish, since they record a higher concentration of protein in the uninfected fish, sheep and pigeon, compared to those infected with Postgangesia armata, Moniezia expansa and Cotugnia cuneata intestinal tapeworms respectively, and also agree with $(31,32)$ in terms of lower protein concentration in tapeworm tissue compared with their host`s tissues. The same as for Dorucu (33) who concluded that infection with Diphyllobothrium spp. were significantly decrease concentration of proteins and lipids in muscles, liver and gonads of the infected Powan fish.

As for the low carbohydrate concentration in $K$. armeniaca when compared with the infected and noninfected B. grypus fish, our results were consistent with those of (30,32). Irshadullah and Mustafa (34) has been verified that glycogen concentration in Clarias batrachus fish that infected with Caryophyllids parasite were lower 34 times than the concentration of glycogen in the uninfected fish. (30) Have been attributed the rise in glycogen concentration in Moniezia expansa that parasitize Caprahircus, to the size of the worm and its location inside the host. Nanware and Bhure (35). Also showed a difference in the glycogen amount in segment of tapeworms that are isolated from Capra hircus.
On the other hands, the present result was not agreeing with that of (9) in term of the relatively low carbohydrate concentration in $K$. armeniaca tissues, Dawood et al. (9) concluded that concentration of carbohydrates was higher than concentration of proteins and lipids in both Ophiotaenia bofonis, the intestine tapeworm of the house frog Bufo viridis viridis, and Cotugnea columbae, the intestinal tapeworm of domestic pigeon Columba livia domestica. Our result was not agreeing also with that of Dorucu (33) who concluded that concentration of proteins and lipids were higher in the muscle and liver tissues of Powan fish those infected with the tapeworm Diphyllobothrium spp, then that in uninfected Powan fish.

Al-kallak (36) has been referred to the high concentration of lipids and proteins compared with carbohydrates in both tapeworms, Kawia sp (parasitize Barbus fish) and Proteocephalus sp. (parasitize Silurus fish, she added that concentration of proteins in Kawia sp was higher than that in Proteocephalus sp. She has been associated between the variation in macromolecules content in the invader helminthes and the nourishment diversity of their hosts. Al-Egaidy (37) reviled that concentration of protein was higher than concentration of carbohydrates and lipids in adult Faschiola gigantica tissues. She correlated between the low concentration of lipids and the disability of these helminthes to split lipids they have been gotten from host as they grow up; besides, they are dependents highly on carbohydrate catabolism to get energy demands. AlNiaeem and Dawood (10) stated that concentration of total 
lipids in the intestinal tapeworm Bothriocephalus acheilognathi was higher than that found in the intestinal tissues of the infected host, Cyprinus carpio fish. And that lipid concentration in the uninfected fish was higher than that in the infected fish. They referred to the role of the invader tapeworm in the consumption of fatty materials found in host intestine, and to the passive effect of the tapeworm on lipids metabolism in the infected fish.

Dorucu (33) explained that the main source of energy in fish are proteins and fats, unlike mammalians, in which the main source of energy is carbohydrates and fats. This may be due to type of fish nutrition, especially the adult. Fish metabolism is adaptive to the type of food added to their ability to remove nitrogenous catabolizes rapidly and continuously, as well as, the activity of lysosomes enzymes is faster in fish compared to mammalians (31). This may explain the higher concentration of proteins and lipids in $B$. grypus intestine. Regarding tapeworm protein content, Hassan and Hashim (32) revealed that tapeworms secrete protease from their tegument, which decompose surrounding host proteins, producing amino acids that are absorbed subsequently by worm tegument, then used by the tapeworm for subsequent protein synthesis.

As for lipid concentration in $K$. armeniaca, our result consists with that of Biswal et al. (31) those reported that concentration of total lipids in intestine of the infected fish was lesser than that of the invading intestinal tapeworm. So as Hassan and Hashim (32) those concluded that concentration of total lipids in the tapeworms Davainea shindei, Lytocestus sp. and Postgangesia inarmata were higher than that in their hosts Gallus gallus domesticus, Clarias batrachus and Silurus triostegus (fish) respectively. Furthermore, tapeworms have no De novo pathway for fatty acids metabolism, and thus absorb fatty acids from host intestine in a relatively high amounts (10). This may explain the low concentration of lipids in the intestine of the invaded fish.

Our result was coming agree with that of Hel et al. (38) in term of the relatively high LDH activity in liver tissues of the infected fish. She recorded an increase in blood glucose and LDH activity in tissues of Tilapia fish those infected with metacercariae of the Pyigidiopsis summa and Geneta cestodes. Hel et al. (38) correlated between the increment in LDH activity in the infected fish with the elevation in anaerobic catabolism of blood glucose as a result of liver and muscle tissues damage.

As for the relatively high LDH activity in $K$. armeneaca tissues, our result consisted with that of (8) who correlate the high activity of LDH in the intestinal tapeworm $C$. dignopora of Gallus gallus domesticus, with the role of this enzyme in energy supply and in the preservation of the cytoplasmic redox state in tapeworm tissues. Al-Egaidy (37) combined the relatively high activity of LDH $(28.66 \mu$ $\mathrm{mol} / \mathrm{min} / \mathrm{mg}$ protein) in Fasciola gigantica tissues with the adaptation of such parasitic trematodes to anaerobic respiration. Dawood et al. (10) referred to the variation and relatively high activity of LDH in the tissues of Ophiotaenia bofonis, the intestine tapeworm of the house frog Bufo viridis viridis, and Cotugnea columbae, the intestinal tapeworm of domestic pigeon Columba livia domestica, they concluded that the variation in level of enzyme activity in the two tapeworms due to the variation in the metabolic rates of their hosts especially during proliferation and activity seasons.

Gluconeogenesis is almost occurring in hepatocytes and in kidney cortex at less extent. it is elevated under certain conditions like starvation, fasting, exercise, stress and in case of some diseases like diabetes and some infectious disease (39). The case that lead to elevation in activity of some enzymes especially the cytosolic enzyme LDH (16). Akinrotim et al. (40) revealed that the elevation of LDH activity under stress conditions (like endoparasites infestation) provides the oxaloacetate that is required for the gluconeogensis pathway to meet the additional supply of glucose for the production of energy under reduced phase of oxidative metabolism. Bao et al. (41) clarified that Sub lethal concentration of copper chloride resulted in significant elevation of LDH activity in muscle and hepatopancreas tissues of the crab Sesarma quadratum. They concluded that the increase in LDH activity may reflect an increased dependence on anaerobic carbohydrate metabolism by the muscle, gills and hepatopancreatic tissues upon exposer to such a toxicant (copper chloride).

In the present work, liver ALT of the infected fish was significantly lesser than that of the uninfected fish, this result was agreeing with Amni et al. (42) who concluded that specific activity of ALT in Fasciola hepatica tissues was higher than that in liver tissues of the infected sheep. But not agree with Ekanem and Yusuf (43) who reported that AST activity was significantly lower in liver of rat infected with Trypanosoma brucei than that of uninfected rats, while there was no significant difference in ALT activity in liver of both infected and uninfected rats.

Our result was not consisted with Al-Naftachi (7) who concluded that ALT activity was approximate in the four cestodes: Bothriocephalus spp. in Heckel fish; Ophiotaenia europaea in snake; Raillietina echinobothrida in gull and Moniezia expansa in sheep.

We hypothesize that the infected fish B. grypus has been stressed and exposed to protein, carbohydrate and lipids deficit in intestinal tissues upon the tapeworm infestation. Such stress factors added to hunger and other factors like tapeworm toxic exudates could change membranes permeability toward membrane bound enzymes like SDH and mitochondrial ALT (41,44). Furthermore, famishing conditions may lead to hypoglycemia and increased $\mathrm{NADH} / \mathrm{NAD}+$ ratio and thus increase dependent on gluconeogenesis to maintain blood glucose levels in the infected fish. Alanine and lactate are the major gluconeogenic precursors that enter gluconeogenesis as 
pyruvate. The high NADH/NAD+ ratio shifts the lactate dehydrogenase equilibrium to lactate, increasing LDH activity. So that, less pyruvate can be formed and therefore, gluconeogenesis is impaired, lead to lessening ALT activity and lowering glucose concentration (45). This explain the low concentration of glucose in intestinal tissues of the infected B. grypus fish that was synchronized with the high LDH and low ALT activity in liver tissues.

On the other hands, Al-Kaabi et al. (46) reviled that $B$. grypus is omnivores fish, but the adult $B$. grypus. is incline to predation rather than herbal nourishment. This may explain the relatively higher concentration of both protein and lipids in the tissues of the invading tapeworm $K$. armeniaca when compared with carbohydrates. At the same time, parasites those living in anaerobic or semi-anaerobic habitat's like intestinal tapeworms, gain their energy almost exclusively through the fermentation of carbohydrate because it is a much better substratum for gaining anaerobic energy than either protein or fat (8). The cytochrome chain in such helminthes is often demand a modified reduction in TCA cycle, the state that demand active LDH enzyme to provide energy and eventually resulted in a low ATP production/mole glucose catalyzed (47). The state that often compensated by high rates of glucose utilization in the parasitic helminthes. And since that tapeworm have no digestive system and get their nutritional demands from host body (48), thus may lead to decrease concentration of these macromolecules in the intestine of the invaded $B$. grypus.

On the other hands, LDH acts as a pivotal enzyme between the glycolytic pathway and the tricarboxylic acid cycle. Thus, in hypoxic environment (like intestinal lumen), some mitochondrial bound enzymes such as $\mathrm{SDH}$, mitochondrial ALT will have inhibited with simultaneous elevation of LDH. Such condition suggests a bias towards the anaerobic glycolytic pathway (41). The state that may explain a relatively higher LDH activity and lesser carbohydrate concentration and ALT activity in tissues of K. armeniaca tapeworm.

\section{Conclusion}

Increase LDH activity and decrease ALT activity in tissues of $K$. armeniaca tapeworm are related to the anaerobic respiration of the tapeworm. Decrease concentration of total proteins, lipids and carbohydrates in the intestinal tissues of the infected fish is associated with the presence of the intestinal tapeworm $K$. armeniaca, and so as the diminution in ALT activity and increase LDH activity in the liver cells of the infected fish. This report suggests that LDH and ALT activity in B. grypus. liver is a sensitive index to measure the influence of intrinsic factors such as endoparasites invasion.

\section{Acknowledgment}

The researchers wanted to dedicate their great thanks to University of Mosul presidency, and to both College of Nursing and College of Pharmacy deanery, for the technical and logistic support to complete the work.

\section{Conflict of interest}

The author declares that there is no conflict of interest.

\section{References}

1. Uner N, Oruc EO, Y, Sevgiler Y, Sahin N, Durmaz H, Usta D. Effects of diazinon on acetylcholinesterase activity and lipid peroxidation in the brain of Oreochromis niloticus. Environ Toxicol Pharmacol. 2006;21:241-245. Doi: 10.1016/J.etap.2005.08.007.

2. Monteiro DA, Rantin FT, Kalinin AL. The effects of selenium on oxidative stress biomarkers in the freshwater characid fish matrinxã, Brycon cephalus exposed to organophosphate insecticide Folisuper 600 BR $^{\circledR}$ (methyl parathion). Comp Biochem Physiol. 2009;149:4049. Doi: 10.1007/s10646-009-0395-1.

3. Modesto MA, Martinez CBR. Roundup causes oxidative stress in liver and inhibits acetylcholinesterase in muscle and brain of the fish $\begin{array}{lll}\text { Prochilodus lineatus. Chemosphere. 2010;78:294- } & \end{array}$ 299.doi.org/10.1016/j.chemosphere.03.042.

4. De Menezes CC, Loro VL, Fonseca MB, Cattaneo RA, Pretto D, Santos Miron A. Oxidative parameters of Rhamdia quelen in response to commercial herbicide containing clomazone and recovery pattern. Pestic Biochem Physiol. 2011;100:145-150. https://doi.org/10.1016/j.pestbp.2011.03.002.

5. Aisien SO, Ogiji EE. Observation on the lipids of Oochoristica agamae (cestoda). Parasitol Res. 1999;75:07-310. DOI: 10.1007/bf00931815 PMID:2704724.

6. Malagón D, Valero BA, Adroher FJ. CO2-fixing enzymes and phosphoenolpyruvate metabolism in the fish parasite Hysterothylacium aduncum (Ascaridoidea, Anisakidae). Dise Aqua Org. 2009;85:217-223. Doi: 10.3354/dao02085.

7. Al-Naftachi MM. Histological and Biochemical studies of some cestode Tapeworms from different vertebrate hosts [PhD dissertation]. Mosul:Department of Biology, College of Sciences, University of Mosul, Iraq;2006. 1-187 p.

8. Waghmare SB, Chavan R J. Some quantitative studies of carbohydrate metabolites in cestod parasite of Gallus gallus domesticus. Intern J parasitol Res. 2010;2(1):01-04. DOI: 10.9735/0975-3702.2.1.1-4

9. Dawood MH, Shareef SY, Thiyab SA. Comparative study for some aspects of energy metabolism in two samples of intestinal cestodes:in house frog and domestic pigeon. Tikrit Med J. 2017;23(1):113-127. https://www.iasj.net/iasj?func=fulltext\&aId $=178145$

10. Al-Niaeemi BH, Dawood MH. Total lipids estimation and fatty acids analysis of Bothriocephalus acheilognathi, a parasitic tapeworm of the common carp Cyrinus carpio (L., 1758) from Tigris. World J Pharm Pharmaceut Sci. 2017;6(9):1641-51. Doi: 1020959/wjpps20179-10110

11. Al-Niaeemi BH, Al-Kallak SN, Mohammad H, Mikael MH. Determination of total concentration of proteins and carbohydrates in Tapeworm Postgangesia armata and intestine of infected and noninfected fish host Siluris glanis. World J Pharm Pharmaceut Sci. 2019;8(3):1-11. Doi: 10.20959/wjpps20193-13024

12. Ninfa AJ, Ballou DP, Benore M. Biochemistry and Biotechnology. USA:John Wiley and Sons;2010. 229-230 p.

13. Kim HS, Lee HE, Yang HK and Kim WH. High lactate dehydrogenase 5 expression correlates with high tumoral and stromal vascular endothelial growth factor expression in gastric cancer. Pathobiol. 2014;81(2):78-85. https://doi.org/10.1159/000357017 
14. Alsaad KM, Al-Autaish HN and. Ahmed JA. Evaluation of cardiac enzymes and acute phase response as biomarkers for rapid diagnosis of myocarditis in calves with FMD. Iraqi Journal of Veterinary Sciences. 2020;34(1):31-37. Doi: 10.33899/ijvs.2020.163584.

15. Muriana FJ, Alvarez-Ossorio MC, Relimpio AM. Purification and characterization of aspartate aminotransferase from the halophile archaebacterium Haloferax mediterranei. Biochem J. 1991;278(1):149-54. Doi:10.1042/bj2780149

16. Mirmiran $P$, Gaeini $Z$, Bahadoran $Z$ and Azizi F. Elevated serum levels of aminotransferases in relation to unhealthy foods intake: Tehran lipid and glucose study. BMC Endocrine Disorders. 2019;19(100):11-18. Doi: 10.1186/s12902-019-0437-5.Alexandre JS, Ribeiro I, Xinning Y, Vikram P, Rajnikanth M, David GS. Liver Microphysiological systems for predicting and evaluating drug effects. Clin Pharmacol Ther. 2019;106(1):139-147. Doi: 10.1002/cpt.1458.

17. Mustafa NG. Effects of Newcastle disease vaccine on the liver and antioxidant enzymes of chicks. Iraqi Journal of Veterinary Sciences. 2018;32(2) :243-247. Doi: 10.33899/ijvs.2019.153856.

18. Ogueji OE. Comparative acute toxicity of chlorpyifos-ethyl (Organophosphate) and lambda-cyhalothrin (Pyrethroid) to the African catfish (C. gariepinus) using some biochemical parameters. Glob J Pure Applid Sci. 2008;14(3):263-269. http://dx.doi.org/10.4314/gjpas.v14i3.16747

19. Abhijith BA, Ramesh M, Poopal, RK. Responses of metabolic and antioxidant enzymatic activities in gill, liver and plasma of Catla catla during methyl parathion exposure. J Basic Applied Zool. 2016;77:3140. Doi: 10.1016/i/jobaz.

20. Rastiannasab A, Afsharmanesh SH, Ruhollah RR, Iman Sh I. Alternations in the liver enzymatic activity of common carp, Cyprinus carpio in response to parasites, Dactylogyrus spp. and Gyrodactylus spp. J Parasite Dis. 2016;40(4):1146-1149. Doi: 10.1007/s12639-0140638-9

21. Nambati EA, Kiarie WC, Francis KT, Bulimo W. Unclear association between levels of Plasmodium falciparum lactate dehydrogenase (PfLDH) in saliva of malaria patients and blood parasitaemia: Diagnostic implications? Malaria Journal. 2018;17(1):12-17. DOI: 10.1186/s12936-017-2151-y

22. Al-Mowla SA. Biochemical parameters in some nematodes, which infect some vertebrates [PhD dissertation]. Mosul:College of Sciences, University of Mosul, Iraq;2011. 1-229 p.

23. Shafaei SH, Farahnak A, Golmohammadi T, Esharghian MR, Molaei Rad MB. Study of Triclabendazole (TCBZ) Effect on Aspartate Transaminase (AST) Activity of Fasciola gigantica parasite and liver enzyme activity assay. J Pharm Care. 2014;2(4):149-53. Doi: 10.1016/0007-1935(92)90048-6.

24. Scholz T, De Chambrier A. Taxonomy and Biology of proteocephalidean cestodes: Current state and perspectives. Helminthol. 2003;40(2):65-77. Doi: 10.1590/S010181751995000400009

25. Gottschalk G. Methods in Microbiology. $1^{\text {st }}$ ed. London: Academic Press;1985. 1-268 p. ISBN:9780080860411

26. Burtis A and Bruns DE. Tietz fundamentals of clinical chemistry and molecular diagnosis. $7^{\text {th }}$ ed. USA: WB Saunders Company;2014. ??-??

27. Wolf PL. Lactate dehydrogenase isoenzyme in myocardial disease. Clin Lab Med. 1989;9(4):655-665. Doi: 10.1016/S02722712(18)30597-3

28. Reitman S, Frankel S. A calorimetric method for the determination of serum glutamic oxaloacetate and glutamic pyruvic transaminase. American J Clin Path. 1957;28:56-63. https://doi.org/10.1093/ajcp/28.1.56

29. Easterling RG. Fundamentals of statistical experimental design and analysis. UK:Wiley Press;2015. $272 \mathrm{p}$.

30. Nanware SS, Bhure DB, Habib MH. Glycogen content in Moniezia expansa and its host intestine. Indian J Applied Res. 2012;4(5):651652 Doi: 10.15373/2249555X/MAY2014/206

31. Biswal D, Nadi AP, Chatterjee S. Biochemical and molecular characterization of the Cyclophyllidean cestode, Cotugnia cuneata
(Meggit, 1924), an endoparasite of domestic pigeons, Columba livia domestica. J Parasit Dis. 2014;38(1):106-110. Doi: 10.1007/s12639012-0203-3

32. Hassan HF, Hashim DS, Abdulla SMA. Identification of some Iraqi fish parasites by using biochemical and molecular protocols. Inter J Current Res Academic Rev. 2016;4(1):54-64. Doi: 10.20546/ijcrar.2016.401.006

33. Dorucu M. Changes in the protein and lipid content of muscle, liver and ovaries in relation to Diphyllobothrium spp. (Cestoda) infection in Powan (Coregonus lavaretus) from loch lomond, Scotland. Turk J Zool. 2000;24:211-21. Doi: 10.1111/j.1365-2761.2007.00816

34. Irshadullah M, Mustafa Y. Histopathological changes in naturallyinfected Chirruhsnowtrout, Schizothorax esocinus (Heckel), with Adenoscolexoreini (Caryophyllidea: Capingentidae). Arch Pol Fish. 2010;18:179-182. Doi: 10.2478/v10086-010-0020-1.

35. Nanware SS, Bhure DB. Diversity of tapeworms from avian and mammalian host from Marathwada region India. Indian J Applied Res. 2011;3(9):67-69. Doi: 10.15373/2249555X/SEPT2013/176

36. Al-Kallak SN. Morphological, histological and chemical studies on two cestodes model as fish parasites [PhD dissertation] Mosul: College of Science, University of Mosul, Iraq;2001. 1-198 p.

37. Al-Egaidy Sh O. Study of some biochemical and histochemical changes in one species of genus Fasciola (Fasciola gigantica) isolated from cattle livers [MSc thesis]. Mosul: College of Sciences, University of Mosul, Iraq;2011. 1-112 p.

38. He1 J, Qiang J, Gabriel1 NN, Xu1 P, Runqing Y, Yang R. Effect of feeding-intensity stress on biochemical and hematological indices of Gift Tilapia (Oreochromis niloticus). Turk J Fish Aqua Sci. 2015:15:303-310. DOI: 10.4194/1303-2712-v15_2_12.

39. Nuttall FQ, Ngo A, Gannon MC. Regulation of hepatic glucose production and the role of gluconeogenesis in humans: Is the rate of gluconeogenesis constant? Diabetis Metabolism Res Rev. 2008;24(6):438-458. Doi: $10.1002 \mathrm{ldm}$ rr.863

40. Akinrotim OA, Edun OM, Ukwe OIK. Effects of anaesthetics on metabolic enzyme activities in african catfish, Clarias gariepinus (Burchell, 1822). J Fisheries Sci. 2018;12(1):022-028. Doi: 10.12691/aees-1-3-3

41. Bao J, Li X, Xing Y, Jiang H. Respiratory metabolism and antioxidant response in chinese mitten crab eriocheir sinensis during air exposure and subsequent immersion. Front Physiol. 2019;10(907):11-21. Doi: 10.3389/fphys.2019.00907

42. Amni F, Farahnak A, Golmohammadi T, Eshraghian MR, Rad MM. Efficacy of nitroxynil against Fasciola hepatica resistant to triclabendazole in a naturally infected sheep flock. Parasitol Res. 2010;107(5):1205-11. Doi: 10.1007/s00436-010-1989-5

43. Ekanem JT, Yusuf OK. Activities of alkaline phosphatase, glutamate oxaloacetate transaminase and glutamate pyruvate transaminase in liver and serum of Trypanosoma brucei-infected rats treated with honey. Biokem. 2005;17(2):185-191. Doi: 10.4314/biokem.v17i2.32606

44. Halton DW. Nutritional adaptations to parasitism within the Platyhelminthes. J Parasit. 1997;27(6):693-704. Doi: 10.1016/S00207519(97)00011-8

45. Selwood T, Jaffe EK. Dynamic dissociating homo-oligomers and the control of protein function. Arch Biochem Biophys. 2012;519(2):13143. Doi:10.1016/j.abb.2011.11.020

46. Al-Kaabi KM, Salman TS, Raheg AM, Ruhayej AM, Hasan SM. Seasonal variation in natural nutrition of Arabic Barbus grypus (Heckel, 1843) in Euphrates river at Al-Mosaib town-Iraq. Diala J Agricul Res. 2018;10(2):15-25. https://iasj.net/iasj?func $=$ article\&aId $=161570$

47. Mandal FB. Human Parasitology. $2^{\text {nd }}$ ed. Delhi:PHI Learning Private;2015. 1-317 p. ISBN-978-81-203-5115-8.

48. Mondal M, Mukhopchyay D, Ghosh D, Dey C, Misra KK. Analysis of major lipid classes and their fatty acids in cestode parasite domestic fowle, Raillietina (Fuhrmannetta) echinobothrida. Proc Zool Soc. 2009;62(2):131-137. Doi: 10.1007/s12595-009-0015-3 
وجود انخفاض معنوي في تركيز البروتينات و الكربو هيدرات و الدهون

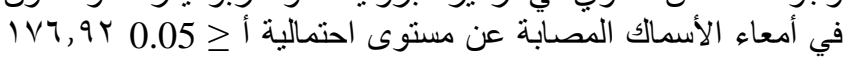

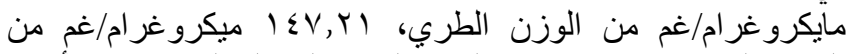

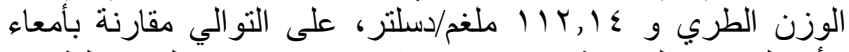

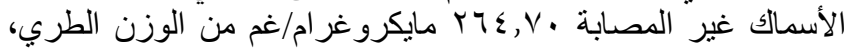

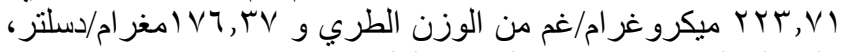

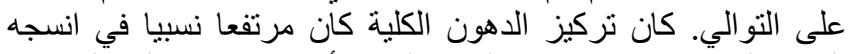

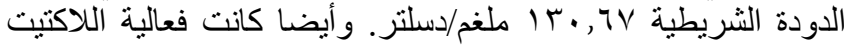

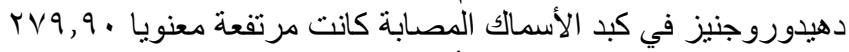

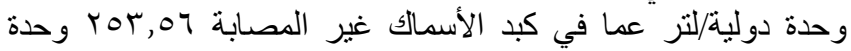

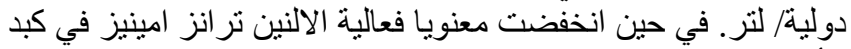

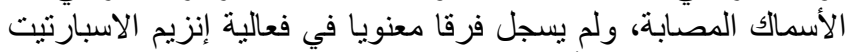

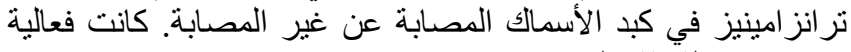

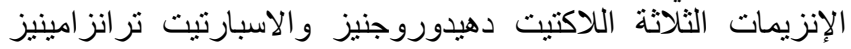

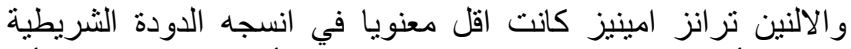

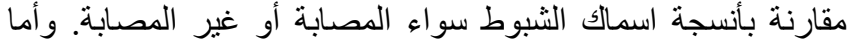

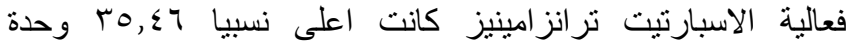

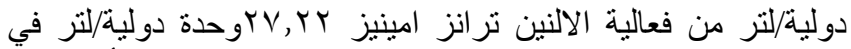

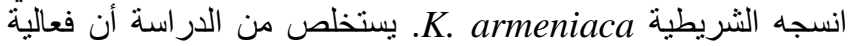

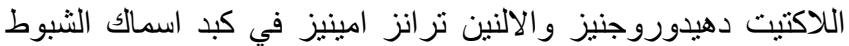

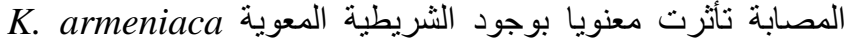
ومن الممكن اعتبار ها كدلائل حيوية لإصابة الأسماك بالدودة الثريطية.

\section{التتبع الحيوي للفعاليات الأيضية في الدودة الشريطية} مع Khawia armeniaca (Cholodkovsky,1915) Barbus (Hekle,1843) مضيفها اسماك الثبوط) grypus

\author{
بشرى حسن النعيمي' و مروة هاشم داؤد؟
}

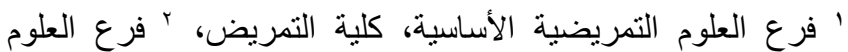
المختبرية السريرية، كلية الصيدلة، جامعة الموصل، الموصل، العربة العراق العرم

الخلاصة

هدفت الدراسة الحالية إلى معرفة العلاقة بين الإصابة بالدودة

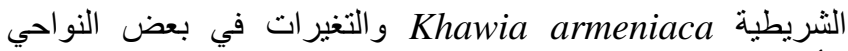
الأيضية في كل من الثريطية المعوية ومضيفها اسماك الثينية الثبوط

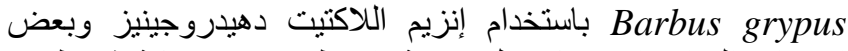

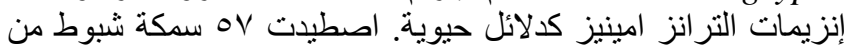

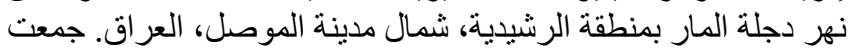

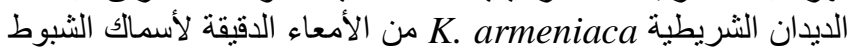

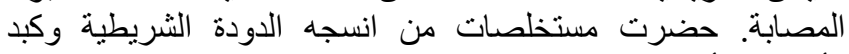

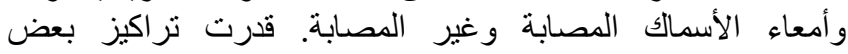

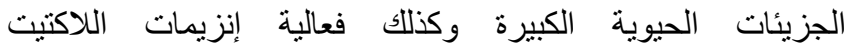

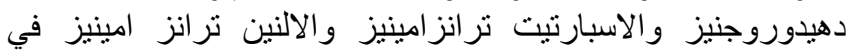

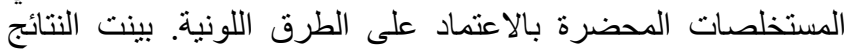

